\title{
Association of IL-1 $\alpha$ gene polymorphism with susceptibility to type 1 diabetes in Chinese children
}

\author{
X. Zhou', J.G. Ca ${ }^{2}$, H. Peng', J.L. Wang' and G.M. Li ${ }^{2}$ \\ ${ }^{1}$ Department of Pediatrics, \\ Jinan Central Hospital Affiliated to Shandong University, Jinan, China \\ ${ }^{2}$ Department of Pediatrics, \\ Shandong Provincial Hospital Affiliated to Shandong University, Jingshi, \\ Jinan, China \\ Corresponding author: G.M. Li \\ E-mail: hpengjnsd@163.com
}

Genet. Mol. Res. 15 (3): gmr.15038025

Received December 17, 2015

Accepted January 15, 2016

Published August 26, 2016

DOI http://dx.doi.org/10.4238/gmr.15038025

Copyright (C) 2016 The Authors. This is an open-access article distributed under the terms of the Creative Commons Attribution ShareAlike (CC BY-SA) 4.0 License

\begin{abstract}
The interleukin- $1 \alpha$ (IL-1 $\alpha)$ gene appears to play a role in the pathogenesis of type 1 diabetes (T1D). Therefore, the aim of this study was to investigate the contribution of the IL-1 rs1800587 gene polymorphism to susceptibility to T1D in Chinese children. This casecontrol study included 332 Chinese children with T1D and 332 healthy controls. Identification of genetic variants of rs 1800587 in the IL- $1 \alpha$ gene was performed by polymerase chain reaction amplification. The IL-1 $\alpha$ rs 1800587 polymorphism demonstrated a significant association with T1D risk. The allelic frequency significantly differed between the T1D and control groups [odds ratio $(\mathrm{OR})=0.7 ; 95 \%$ confidence interval $(\mathrm{CI})=0.52-0.86 ; \mathrm{P}=0.002]$. Furthermore, significant differences were observed in the dominant model $(\mathrm{CC} / \mathrm{CT}+\mathrm{TT}$; OR $=0.6 ; 95 \% \mathrm{CI}=$
\end{abstract}


$0.46-0.85 ; \mathrm{P}=0.003)$. In T1D patients, the prevalence of hypertension in $\mathrm{T}$ allele carriers was 4.2 -fold higher than that in $\mathrm{C}$ allele carriers, $(95 \% \mathrm{CI}=2.67-6.58 ; \mathrm{P}<0.001)$. In conclusion, the present study found evidence of a significant association between the rs1800587 polymorphism in the IL-1 $\alpha$ gene and T1D.

Key words: Interleukin-1 $\alpha$; Rs 1800587; Type 1 diabetes; Polymorphism

\section{INTRODUCTION}

Type 1 diabetes (T1D) is a complex, multigenetic autoimmune disease characterized by destruction of pancreatic $\beta$ cells, resulting in insulin-dependence of patients (Tang et al., 2015). It was estimated that as of 2014, 38.7 million people have T1D worldwide, accounting for about $10 \%$ of all patients diagnosed with diabetes (Buchmann et al., 2015). Diabetes can, at the very least, double a person's risk of death (Kalra et al., 2015). The incidence of T1D varies among different populations (Bluestone et al., 2010) owing to the interplay between multiple genetic and environmental risk factors, which are still poorly recognized (Noble et al., 1996; Gale, 2002; Hober and Sauter, 2010).

Human leukocyte antigen (HLA) class II genes at chromosome 6p21 were proven to be a major susceptibility locus, accounting for 30-50\% of the genetic risk for T1D (Noble et al., 1996). Genome-wide association studies have identified several non-HLA loci with smaller effects on T1D risk, including the insulin gene, the protein tyrosine phosphatase nonreceptor 22 (PTPN22) gene, and the protein tyrosine phosphatase N2 (PTPN2) gene (Todd et al., 2007; Steck et al., 2012).

Interleukin- $1 \alpha(\mathrm{IL}-1 \alpha)$ is a pro-inflammatory cytokine that plays a role in the regulation of immune responses, inflammatory processes, hematopoiesis, and induction of apoptosis in response to cell injury. IL-1 $\alpha$, which mainly comes from activated macrophages, neutrophils, epithelial cells, and endothelial cells, is considered to have an effect in the pathogenesis of disc degeneration by increasing the production of extracellular matrix (ECM) degradation enzymes and by inhibiting ECM synthesis (Ye et al., 2007; Phillips et al., 2013). As a pro-inflammatory molecule, IL- $1 \alpha$ is mainly produced by macrophages and natural killer cells as a result of T cell-derived cytokines (e.g., interferon- $\gamma$ ) or bacterial stimulation. IL-1 $\alpha$ binds to the IL-1 receptor, eliciting signal transduction and the corresponding biological effects (Luheshi et al., 2009; Risbud and Shapiro, 2014).

Different single nucleotide polymorphisms (SNPs) may lead to structurally different proteins, altered biological roles, or abnormal transcription rates. The SNP rs 1800587 in IL$1 \alpha$ has been shown to be associated with many autoimmune diseases, including systemic sclerosis (Abtahi et al., 2015). Luotola et al. (2011) have identified the positive association of the rs 1800587 polymorphism in IL-1 $\alpha$ with risk of type 2 diabetes (T2D). However, no study has investigated the association of this SNP with T1D risk. Therefore, the purpose of the present study was to investigate the contribution of the IL- $1 \alpha$ gene polymorphism rs 1800587 to susceptibility to T1D in a Chinese population.

\section{MATERIAL AND METHODS}

This case-control study was approved by the Institutional Board Review of Shandong Provincial Hospital Affiliated to Shandong University.

Genetics and Molecular Research 15 (3): gmr.15038025 


\section{Study subjects}

A total of 332 T1D patients, who were diagnosed according to the criteria established by the American Diabetes Association (2015), were recruited from Shandong Provincial Hospital Affiliated to Shandong University. There were 332 health volunteers without family history of diabetes and any autoimmune diseases in the control group (1:1 ratio of T1D patients to controls). All T1D patients were managed with two or more doses of insulin per day. T1D patients who had other autoimmune diseases, including myasthenia gravis, Behcet's disease, psoriasis, and multiple sclerosis, were excluded. Each participant gave written informed consent. All characteristics of patients were collected from medical records or using questionnaires, including age, gender, body mass index (BMI), family history, blood pressure, serum biomarkers [glycated hemoglobin (GHbA1c), triglyceride levels, cholesterol levels, etc.], and medical complications.

\section{Genetic analysis}

A total of $10 \mathrm{~mL}$ venous blood was obtained from each participant for genomic DNA extraction and stored at $-80^{\circ} \mathrm{C}$ until further analysis. DNA was extracted using a DNA extraction kit (QIAamp DNA mini Kit, Qiagen, Hilden, Germany) according to manufacturer instructions. Samples were genotyped for the ADD1 rs1800587 polymorphism with TaqMan allelic discrimination assays with an ABI 7900 system (Applied Biosystems, FosterCity, CA, USA). The primer sequences in this study were as follows: 5'-GAGAAGACAAGATGGCTGAACTCT-3' (forward) and 5'-GTCTTCGACTTGGGACTGCTT-3' (reverse). The TaqMan assays utilized $100 \mathrm{ng}$ genomic DNA in reaction volumes of $20 \mu \mathrm{L}$. The polymerase chain reactions (PCR) were performed as follows: enzyme activation step of $10 \mathrm{~min}$ at $95^{\circ} \mathrm{C}$, followed by 40 cycles of $92^{\circ} \mathrm{C}$ for $15 \mathrm{~s}$ and annealing and extension at $60^{\circ} \mathrm{C}$ for $1 \mathrm{~min}$. PCR genotyping results were tested using the SDS allelic discrimination software (Applied Biosystems). Approximately $10 \%$ of the samples were duplicated for analysis to ensure $100 \%$ concordance.

\section{Statistical analysis}

All statistical analyses were performed using the SPSS ver. 19.0 software package (SPSS, Chicago, IL, USA). Hardy-Weinberg equilibrium (HWE) was examined using the $\chi^{2}$ test. Comparisons of allele and genotype distributions in the cases and controls were determined by means of $2 \times 3$ - and $2 \times 2$-contingency tables using the $\chi^{2}$ test. The $\chi^{2}$ test and Kolmogorov-Smirnov test with one-way ANOVA were performed to compare baseline characteristics of subjects between genotypes. A P $<0.05$ was considered significant for all statistical analyses.

\section{RESULTS}

The main clinical and laboratory characteristics of T1D patients are listed in Table 1. Mean age of T1D patients at diagnosis was $9.6 \pm 5.3$ years and the mean BMI was $19.2 \pm 4.1$ $\mathrm{kg} / \mathrm{m}^{2}$. Males comprised $41.0 \%$ of the T1D patients. Genotype frequencies in controls were in agreement with $\operatorname{HWE}(\mathrm{P}=0.192)$.

Genetics and Molecular Research 15 (3): gmr.15038025 


\section{Table 1. Demographic characteristics of T1D patients.}

\begin{tabular}{l|c}
\hline Variables & T1D (N =332) \\
\hline Age (years) & $9.6 \pm 5.3$ \\
\hline Gender (M/F) & $136 / 196$ \\
\hline BMI & $19.2 \pm 4.1$ \\
\hline Blood pressure & $285 / 47$ \\
\hline Normal/hypertension & $1.83 \pm 0.71$ \\
\hline LDL cholesterol (mM) & $1.37 \pm 0.61$ \\
\hline HDL cholesterol (mM) & $1.43 \pm 0.42$ \\
\hline Triglycerides (mM) & $8.8 \pm 4.18$ \\
\hline GHbAlc (\%) & $32(9.63 \%)$ \\
\hline Familial history & \\
\hline Complications & $313 / 19$ \\
\hline None/microalbuminuria & \\
\hline
\end{tabular}

$\mathrm{M}=$ male; $\mathrm{F}$ = female; $\mathrm{BMI}=$ body mass index; $\mathrm{LDL}=$ low-density lipoprotein; $\mathrm{HDL}=$ high-density lipoprotein; $\mathrm{GHbA1c}=$ glycated hemoglobin A1c.

Genotype and allele frequencies of the IL- $1 \alpha$ rs1800587 polymorphism in T1D patients and healthy controls are depicted in Table 2. We compared the rs 1800587 variation between 332 T1D patients and 332 healthy controls from Chinese teenagers. After comparison of genotype and allele frequencies, the IL- $1 \alpha$ rs 1800587 polymorphism demonstrated a significant association with T1D risk. Although we did not observe significant differences in genotype model analysis, the allelic frequency differed significantly between the groups [odds ratio $(\mathrm{OR})=0.7 ; 95 \%$ confidence interval $(\mathrm{CI})=0.52-0.86 ; \mathrm{P}=0.002$ ]. Furthermore, significant difference was also observed in the dominant model $(\mathrm{CC} / \mathrm{CT}+\mathrm{TT}$; OR $=0.6$; $95 \% \mathrm{CI}=0.46-0.85 ; \mathrm{P}=0.003$; Table 2).

Table 2. Distribution of rs 1800587 genotypes and alleles in Chinese children with T1D and controls.

\begin{tabular}{l|c|c|c}
\hline & T1D $(\mathrm{N}=332)$ & Controls $(\mathrm{N}=332)$ & P value \\
\hline Genotype model & & & 0.082 \\
\hline CC & $171(70.9 \%)$ & $112(67.8 \%)$ & \\
\hline CT & $140(24.8 \%)$ & $11(5.7 \%)$ & 0.002 \\
\hline TT & $21(4.3 \%)$ & & 530 \\
\hline Allele model & 482 & 134 & 0.003 \\
\hline C & 182 & $209 / 123$ & \\
\hline T & $171 / 161$ & & 0.070 \\
\hline Dominant model & & $13 / 269$ & \\
\hline CC/CT TT & $6 / 135$ & & \\
\hline Recessive model & & & \\
\hline TT/CT + CC & & & \\
\hline
\end{tabular}

Next, we analyzed the correlation of the distributions of IL-1 $\alpha$ polymorphism genotypes and alleles with the clinicopathological features in T1D patients (Table 3). No statistically significant differences were present between frequencies of IL-1 $\alpha$ alleles $(\mathrm{C} / \mathrm{T})$ and each variable, including gender, BMI, presence of complications, GHbA1c level, family history, and the levels of LDL cholesterol, HDL cholesterol, and triglycerides ( $\mathrm{P}>0.05)$. However, the prevalence of hypertension in $\mathrm{T}$ allele carriers was 4.2 -fold higher than in $\mathrm{C}$ allele carriers in T1D patients $(95 \% \mathrm{CI}=2.67-6.58 ; \mathrm{P}<0.001$; Table 3$)$.

Genetics and Molecular Research 15 (3): gmr.15038025 
Table 3. Distribution of rs1800587 genotypes and alleles in relation to the clinicopathological features of T1D patients.

\begin{tabular}{l|c|c|c|c|c|c|c}
\hline Variables & CC $(171)$ & CT $(140)$ & TT $(21)$ & P value & C $(482)$ & T $(182)$ & P value \\
\hline Age at onset $(\leq 10 />10$ years) & $96 / 75$ & $90 / 50$ & $14 / 7$ & 0.089 & $282 / 200$ & $118 / 64$ & 0.137 \\
\hline Gender $(\mathrm{M} / \mathrm{F})$ & $72 / 99$ & $54 / 86$ & $10 / 11$ & 0.700 & $198 / 284$ & $74 / 108$ & 0.922 \\
\hline BMI & $18.7 \pm 4.1$ & $19.1 \pm 3.9$ & $19.8 \pm 3.7$ & 0.516 & $18.9 \pm 4.3$ & $19.6 \pm 3.6$ & 0.271 \\
\hline Hypertension $(+/-)$ & $10 / 161$ & $22 / 118$ & $15 / 6$ & $0.001^{*}$ & $42 / 440$ & $52 / 130$ & $<0.001^{*}$ \\
\hline LDL cholesterol $(\mathrm{mM})$ & $1.73 \pm 0.68$ & $1.84 \pm 0.52$ & $1.81 \pm 0.72$ & 0.351 & $1.82 \pm 0.53$ & $1.84 \pm 0.71$ & 0.143 \\
\hline HDL cholesterol $(\mathrm{mM})$ & $1.34 \pm 0.41$ & $1.36 \pm 0.52$ & $1.42 \pm 0.33$ & 0.438 & $1.34 \pm 0.43$ & $1.35 \pm 0.63$ & 0.221 \\
\hline Triglycerides $(\mathrm{mM})$ & $1.37 \pm 0.46$ & $1.46 \pm 0.35$ & $1.42 \pm 0.41$ & 0.382 & $1.33 \pm 0.52$ & $1.41 \pm 0.39$ & 0.214 \\
\hline GHbAlc $($ mean $\pm \mathrm{SD})$ & $8.2 \pm 2.11$ & $8.5 \pm 2.47$ & $8.8 \pm 3.13$ & 0.887 & $8.8 \pm 2.92$ & $8.7 \pm 3.32$ & 0.693 \\
\hline Familiar history $(+/-)$ & $15 / 156$ & $12 / 128$ & $5 / 16$ & 0.138 & $42 / 440$ & $22 / 160$ & 0.189 \\
\hline Complications $(+/-)$ & $10 / 161$ & $6 / 134$ & $3 / 18$ & 0.448 & $26 / 456$ & $12 / 170$ & 0.553 \\
\hline
\end{tabular}

*Significant difference. $\mathrm{M}=$ male; $\mathrm{F}=$ female; $\mathrm{BMI}=$ body mass index; $\mathrm{LDL}=$ low-density lipoprotein; $\mathrm{HDL}=$ high-density lipoprotein; GHbA1c = glycated hemoglobin A1c.

\section{DISCUSSION}

In this population-based report, we demonstrated that the IL-1 $\alpha$ rs 1800587 polymorphism is associated with T1D risk in Chinese children. Our results showed that the presence of the T allele could increase risk of T1D. Moreover, for the T1D patients, T allele carriers had a higher prevalence of hypertension than the $\mathrm{C}$ allele carriers. While there have been many reports concerning the association of this IL- $1 \alpha$ gene polymorphism with T2D, no studies have investigated its role in susceptibility to T1D. To our knowledge, this is the first study to investigate the role of the IL-1 $\alpha$ rs1800587 polymorphism in T1D risk.

T1D is a complex, chronic autoimmune disease featuring T cell-mediated destruction of pancreatic $\beta$ cells and subsequent dependence on exogenous insulin (Nokoff et al., 2012). Significant familial aggregation and convincing demonstrations of multiple genetic linkages suggest a genetic component as a risk factor in the pathogenesis of T1D (Noble and Erlich, 2012). Although numerous previous studies have investigated the association between genetic variants and the susceptibility to T1D, the exact mechanisms by which these genes confer T1D susceptibility remain unclear. Therefore, it is necessary to identify more potential genes playing roles in T1D susceptibility.

Diabetes has also been recognized as a disease mediated by inflammatory and immune responses, which lead to impaired signaling of insulin and selective destruction of $\beta$ cells. Therefore, cytokines play an important role in this mechanism. IL-1 has a central role in regulation of inflammatory and immune responses, and IL- $1 \alpha$ and IL-1 $\beta$ are pro-inflammatory cytokines (Banerjee and Saxena, 2012). Polymorphisms in the IL-1 gene have been reported to be associated with obesity, which is a risk factor for the onset of diabetes (Carter et al., 2008), and play a role in glucose homeostasis and diabetes prevalence (Luotola et al., 2009). The IL-1 gene cluster on chromosome 2q, particularly IL-1 $\alpha$, has been implicated in susceptibility to a large number of neoplastic, autoimmune, and chronic inflammatory disorders (Timms et al., 2004; Han et al., 2010; Liu et al., 2010). Luotola et al. (2009) reported that the rs1800587 polymorphism in IL-1 $\alpha$ was associated with higher blood glucose in a cross-sectional study (Luotola et al., 2009). Therefore, we conducted this study to investigate whether the rs 1800587 polymorphism in the IL-1 $\alpha$ gene plays a role in T1D risk.

Luotola et al. (2011) demonstrated that the genetic variations of rs1800587 in the IL-1 $\alpha$ gene might have an association with the risk of T2D (Luotola et al., 2011). Batool et 
al. (2014) also reported that rs 1800587 was associated with T2D at the haplotype level in a Pakistani population (Batool et al., 2014). In our study, the results indicated an association between the rs1800587 polymorphism in the IL-1 $\alpha$ gene with T1D risk. The presence of the $\mathrm{T}$ allele significantly increased the risk of T1D. Moreover, the diabetic patients who were carriers of the $\mathrm{T}$ allele had a higher risk of hypertension compared with those who were $\mathrm{C}$ allele carriers.

In the present study, several limitations should be noted when interpreting the results. First, the relatively small sample size may affect the power in statistical analysis. Second, we should replicate the results in additional individuals, which may decrease potential false positives. Third, other potentially relevant SNPs that might also play important roles in T1D should be examined. Last, we have not performed a functional study to further reveal the mechanism of how the genetic polymorphisms in IL-1 $\alpha$ affect T1D risk.

In conclusion, the present study identified a significant association between the rs1800587 SNP in the IL-1 $\alpha$ gene and T1D. Further multicenter studies, including larger sample sizes, and analysis of gene-gene interactions are necessary to confirm these results in the Chinese population.

\section{Conflicts of interest}

The authors declare no conflict of interest.

\section{REFERENCES}

Abtahi S, Farazmand A, Mahmoudi M, Ashraf-Ganjouei A, et al. (2015). IL-1A rs1800587, IL-1B rs1143634 and IL1R1 rs2234650 polymorphisms in Iranian patients with systemic sclerosis. Int. J. Immunogenet. 42: 423-427. http:// dx.doi.org/10.1111/iji.12212

American Diabetes Association (2015). (2) Classification and diagnosis of diabetes. Diabetes Care 38 (Suppl): S8-S16. http://dx.doi.org/10.2337/dc15-S005

Banerjee M and Saxena M (2012). Interleukin-1 (IL-1) family of cytokines: role in type 2 diabetes. Clin. Chim. Acta 413: 1163-1170. http://dx.doi.org/10.1016/j.cca.2012.03.021

Batool A, Jahan N, Sun Y, Hanif A, et al. (2014). Genetic association of IDE, POU2F1, PON1, IL1 $\alpha$ and IL1 $\beta$ with type 2 diabetes in Pakistani population. Mol. Biol. Rep. 41: 3063-3069. http://dx.doi.org/10.1007/s11033-014-3165-y

Bluestone JA, Herold K and Eisenbarth G (2010). Genetics, pathogenesis and clinical interventions in type 1 diabetes. Nature 464: 1293-1300. http://dx.doi.org/10.1038/nature08933

Buchmann N, Norman K, Steinhagen-Thiessen E, Demuth I, et al. (2015). [Pulmonary function in elderly subjects with metabolic syndrome and type II diabetes : Data from the Berlin Aging Study II]. Z. Gerontol. Geriatr. http://dx.doi. org/10.1007/s00391-015-0958-0

Carter KW, Hung J, Powell BL, Wiltshire S, et al. (2008). Association of Interleukin-1 gene polymorphisms with central obesity and metabolic syndrome in a coronary heart disease population. Hum. Genet. 124: 199-206. http://dx.doi. org $/ 10.1007 / \mathrm{s} 00439-008-0540-6$

Gale EA (2002). The rise of childhood type 1 diabetes in the 20th century. Diabetes 51: 3353-3361. http://dx.doi. org/10.2337/diabetes.51.12.3353

Han W, Kang SY, Kang D, Park SK, et al. (2010). Multiplex genotyping of 1107 SNPs from 232 candidate genes identified an association between IL1A polymorphism and breast cancer risk. Oncol. Rep. 23: 763-769.

Hober D and Sauter P (2010). Pathogenesis of type 1 diabetes mellitus: interplay between enterovirus and host. Nat. Rev. Endocrinol. 6: 279-289. http://dx.doi.org/10.1038/nrendo.2010.27

Kalra S, Aamir AH, Raza A, Das AK, et al. (2015). Place of sulfonylureas in the management of type 2 diabetes mellitus in South Asia: A consensus statement. Indian J. Endocrinol. Metab. 19: 577-596. http://dx.doi.org/10.4103/2230$\underline{8210.163171}$

Liu N, Li X, Liu C, Zhao Y, et al. (2010). The association of interleukin-1alpha and interleukin-1beta polymorphisms

Genetics and Molecular Research 15 (3): gmr.15038025 
with the risk of Graves' disease in a case-control study and meta-analysis. Hum. Immunol. 71: 397-401. http://dx.doi. org/10.1016/j.humimm.2010.01.023

Luheshi NM, Rothwell NJ and Brough D (2009). Dual functionality of interleukin-1 family cytokines: implications for anti-interleukin-1 therapy. Br. J. Pharmacol. 157: 1318-1329. http://dx.doi.org/10.1111/j.1476-5381.2009.00331.x

Luotola K, Pääkkönen R, Alanne M, Lanki T, et al.; Health 2000 AIRGENE Study Groups (2009). Association of variation in the interleukin-1 gene family with diabetes and glucose homeostasis. J. Clin. Endocrinol. Metab. 94: 4575-4583. http://dx.doi.org/10.1210/jc.2009-0666

Luotola K, Pietilä A, Zeller T, Moilanen L, et al.; Health 2000 and FINRISK97 Studies (2011). Associations between interleukin-1 (IL-1) gene variations or IL-1 receptor antagonist levels and the development of type 2 diabetes. $J$. Intern. Med. 269: 322-332. http://dx.doi.org/10.1111/j.1365-2796.2010.02294.x

Noble JA and Erlich HA (2012). Genetics of type 1 diabetes. Cold Spring Harb. Perspect. Med. 2: a007732. http://dx.doi. org/10.1101/cshperspect.a007732

Noble JA, Valdes AM, Cook M, Klitz W, et al. (1996). The role of HLA class II genes in insulin-dependent diabetes mellitus: molecular analysis of 180 Caucasian, multiplex families. Am. J. Hum. Genet. 59: 1134-1148.

Nokoff NJ, Rewers M and Cree Green M (2012). The interplay of autoimmunity and insulin resistance in type 1 diabetes. Discov. Med. 13: 115-122.

Phillips KL, Jordan-Mahy N, Nicklin MJ and Le Maitre CL (2013). Interleukin-1 receptor antagonist deficient mice provide insights into pathogenesis of human intervertebral disc degeneration. Ann. Rheum. Dis. 72: 1860-1867. http://dx.doi.org/10.1136/annrheumdis-2012-202266

Risbud MV and Shapiro IM (2014). Role of cytokines in intervertebral disc degeneration: pain and disc content. Nat. Rev. Rheumatol. 10: 44-56. http://dx.doi.org/10.1038/nrrheum.2013.160

Steck AK, Wong R, Wagner B, Johnson K, et al. (2012). Effects of non-HLA gene polymorphisms on development of islet autoimmunity and type 1 diabetes in a population with high-risk HLA-DR,DQ genotypes. Diabetes 61: 753-758. http://dx.doi.org/10.2337/db11-1228

Tang W, Cui D, Jiang L, Zhao L, et al. (2015). Association of common polymorphisms in the IL2RA gene with type 1 diabetes: evidence of 32,646 individuals from 10 independent studies. J. Cell. Mol. Med. 19: 2481-2488. http:// dx.doi.org/ $10.1111 /$ jcmm. 12642

Timms AE, Crane AM, Sims AM, Cordell HJ, et al. (2004). The interleukin 1 gene cluster contains a major susceptibility locus for ankylosing spondylitis. Am. J. Hum. Genet. 75: 587-595. http://dx.doi.org/10.1086/424695

Todd JA, Walker NM, Cooper JD, Smyth DJ, et al.; Genetics of Type 1 Diabetes in Finland; Wellcome Trust Case Control Consortium (2007). Robust associations of four new chromosome regions from genome-wide analyses of type 1 diabetes. Nat. Genet. 39: 857-864. http://dx.doi.org/10.1038/ng2068

Ye W, Huang DS, Chen WJ, Li CH, et al. (2007). [Association of 86 bp variable number tandem repeat polymorphism of interleukin-1 receptor antagonist gene with lumbar disc disease]. Nan Fang Yi Ke Da Xие Xиe Bao 27: 1485-1488.

Genetics and Molecular Research 15 (3): gmr.15038025 